\title{
Identification of Canola Roots Endophytic Bacteria and Analysis of Their Potential as Biofertilizers for Canola Crops with Special Emphasis on Sporulating Bacteria
}

\author{
Pilar Martínez-Hidalgo 1,2, José David Flores-Félix 1,3 ${ }^{1}$, Fernando Sánchez-Juanes ${ }^{4,5}$, Raúl Rivas 1,6,7 (D), \\ Pedro F. Mateos 1,6,7, Ignacio Santa Regina 7,8 1 , Álvaro Peix ${ }^{7,8}$, Eustoquio Martínez-Molina 1,6,7, \\ José M. Igual $7,8, *$ (D) and Encarna Velázquez ${ }^{1,6,7}$
}

check for updates

Citation: Martínez-Hidalgo, P.;

Flores-Félix, J.D.; Sánchez-Juanes, F.; Rivas, R.; Mateos, P.F.; Santa Regina, I.; Peix, Á.; Martínez-Molina, E.; Igual, J.M.; Velázquez, E. Identification of Canola Roots Endophytic Bacteria and Analysis of Their Potential as Biofertilizers for Canola Crops with Special Emphasis on Sporulating Bacteria. Agronomy 2021, 11, 1796. https://doi.org/10.3390/ agronomy11091796

Academic Editor: Naeem Khan

Received: 23 July 2021

Accepted: 6 September 2021

Published: 8 September 2021

Publisher's Note: MDPI stays neutral with regard to jurisdictional claims in published maps and institutional affiliations.

Copyright: (c) 2021 by the authors. Licensee MDPI, Basel, Switzerland. This article is an open access article distributed under the terms and conditions of the Creative Commons Attribution (CC BY) license (https:/ / creativecommons.org/licenses/by/ $4.0 /)$.
1 Departamento de Microbiología y Genética, Edificio Departamental de Biología, Universidad de Salamanca, Av. Doctores de la Reina s/n, 37007 Salamanca, Spain; martinezhp@usal.es (P.M.-H.); jdflores@usal.es (J.D.F.-F.); raulrg@usal.es (R.R.); pfmg@usal.es (P.F.M.); emm@usal.es (E.M.-M.); evp@usal.es (E.V.)

2 Departamento de Biología, Geología, Física y Química Inorgánica, Universidad Rey Juan Carlos, Departamental II Despacho 248, Av. Tulipán s/n, 28933 Móstoles, Spain

3 CICS-UBI-Health Sciences Research Centre, University of Beira Interior, 6200-506 Covilhã, Portugal

4 Instituto de Investigación Biomédica de Salamanca (IBSAL), Complejo Asistencial Universitario de Salamanca, Universidad de Salamanca, CSIC, 37007 Salamanca, Spain; fsjuanes@usal.es

5 Departamento de Bioquímica y Biología Molecular, Edificio Departamental de Biología, Universidad de Salamanca, Av. Doctores de la Reina s/n, 37007 Salamanca, Spain

6 Instituto Hispanoluso de Investigaciones Agrarias (CIALE), Universidad de Salamanca, 37185 Villamayor, Spain

7 Unidad Asociada Grupo de Interacción Planta-Microorganismo, Universidad de Salamanca-IRNASA-CSIC, 37002 Salamanca, Spain; ignacio.santaregina@irnasa.csic.es (I.S.R.); alvaro.peix@csic.es (Á.P.)

8 Instituto de Recursos Naturales y Agrobiología de Salamanca, Consejo Superior de Investigaciones Científicas, C/Cordel de Merinas 40-52, 37008 Salamanca, Spain

* Correspondence: mariano.igual@csic.es; Tel.: +34-923-219-606

\begin{abstract}
Canola (Brassica napus L. var. oleracea) is the third most common oil-producing crop worldwide after palm and soybean. Canola cultivation requires the use of chemical fertilizers, but the amount required can be reduced by applying plant growth-promoting bacteria (PGPB). Among PGPB, endophytic bacteria have certain advantages as biofertilizers, but canola endophytic bacteria have rarely been studied. In this work, we identified a collection of bacterial endophytes isolated from canola roots using MALDI-TOF MS, a technique that is still rarely used for the identification of such bacteria, and rrs gene sequencing, a methodology that is commonly used to identify canola endophytes. The results demonstrated that some bacterial isolates from canola roots belonged to the genera Bacillus, Neobacillus, Peribacillus (Pe.), and Terribacillus, but most isolates belonged to the genera Paenibacillus (P.) and Pseudomonas (Ps.). Inoculation of these isolates indicated that several of them could efficiently promote canola seedling growth in hydroponic conditions. These results were then confirmed in a microcosm experiment using agricultural soil, which demonstrated that several isolates of Pseudomonas thivervalensis, Paenibacillus amylolyticus, Paenibacillus polymyxa, Paenibacillus sp. (Paenibacillus glucanolyticus/Paenibacillus lautus group), and Peribacillus simplex (previously Bacillus simplex) could efficiently promote canola shoot growth under greenhouse conditions. Among them, the isolates of Paenibacillus and Peribacillus were the most promising biofertilizers for canola crops as they are sporulated rods, which is an advantageous trait when formulating biofertilizers.
\end{abstract}

Keywords: canola; Brassica napus; rapeseed; endophytic bacteria; MALDI-TOF MS; rrs gene sequencing; plant growth promotion 


\section{Introduction}

Canola (Brassica napus L. var. oleracea) is a plant from the family Cruciferae that is cultivated worldwide due to the quality of the oil obtained from its seeds for both human consumption [1] and biodiesel production [2]. Canola is the third most common oil-producing crop worldwide, after palm and soybean. Its current cultivation area is double its cultivation area in the 1990s, and its use in crop rotation has notably increased in recent decades [3]. The production of canola in the last decade has only increased in some European countries, such as Spain, where canola production increased from 35,500 tonnes in 2009 to 144,770 tonnes in 2019 (http:/ / www.fao.org/faostat/en/\#data/QC, accessed on 1 April 2021) [4], primarily due to biodiesel production [5].

Canola cultivation requires the use of chemical fertilizers, but the amount required can be reduced by applying ecofriendly biofertilizers [6]. These biofertilizers are commonly formulated with plant growth-promoting bacteria (PGPB) [7], which include bacterial endophytes with a high potential for biofertilization [8-10]. Nevertheless, few studies to date have addressed the isolation and identification of canola endophytes, which is an essential step in the design of biofertilizers for this crop [11-16].

The identification of endophytic bacteria isolated from canola roots has primarily been performed through rrs gene sequence analysis [11-16]. This methodology, together with MALDI-TOF MS (matrix-assisted laser desorption/ionization time-of-flight mass spectrometry) form the current basis of "culturomics", a term introduced in works concerning the human gut microbiome $[17,18]$ that has also been used in works aiming to achieve the isolation and identification of plant endophytic bacteria [19]. Nevertheless, MALDI-TOF MS has rarely been used to date for the identification of bacterial endophytes [20-25] and, to the best of our knowledge, never before for those of canola.

The isolation and identification of bacterial endophytes are essential steps in order to study the effects these endophytes exert on plant growth, which in turn is an essential step in the selection of bacterial strains for use as biofertilizers [26]. In the case of canola, most works to date have focused on gram-negative endophytic bacteria, and several works have shown that inoculation with endophytic strains of Agrobacterium, Phyllobacterium, Pseudomonas, Variovorax, Achromobacter, Chryseobacterium, Klebsiella, and Pantoea improved canola seedling growth in hydroponic or microcosm conditions [11,12,15,27]. However, information regarding the effects of gram-positive endophytes on canola growth is notably scarce [15], and there have been no studies concerning the effects of these bacteria on microcosm conditions.

Therefore, the aims of this work were: (i) to identify canola bacterial endophytes through MALDI-TOF MS, along with rrs gene sequencing; (ii) to analyze their effect on canola growth via assays carried out under hydroponic conditions; and (iii) to evaluate the potential of selected isolates as canola growth promoters in agricultural soil under greenhouse conditions.

\section{Materials and Methods}

\subsection{Isolation of Bacterial Endophytes}

Canola plants in the phenological stage of inflorescence emergence were collected in April 2016 from two agricultural fields at Medina de Rioseco (Valladolid province, Castilla y León region, Spain; $41^{\circ} 52^{\prime} 59^{\prime \prime} \mathrm{N} 5^{\circ} 02^{\prime} 34^{\prime \prime} \mathrm{W}$ ). Plants were uprooted from the soil, kept refrigerated, and shipped to the laboratory, where they were processed upon arrival. Root bacterial endophytes were isolated as follows: roots were thoroughly washed in tap water, then washed in sterile Petri dishes containing sterile distilled water to remove any remnants of soil. The roots were then excised carefully and cut into 1 to $2 \mathrm{~cm}$ long fragments. They were then surface sterilized with sodium hypochlorite (2\%) for $2 \mathrm{~min}$. Surface-disinfected roots were washed 5 times in sterile distilled water. An aliquot of water from the last washing step of each sample after the disinfection protocol was plated as a disinfection control. No bacterial growth was observed in those plates. Each root fragment was smashed in a sterile mortar. The crushed root was serially diluted with sterile distilled 
water. Then, $100 \mu \mathrm{L}$ of the $10^{-1}, 10^{-2}, 10^{-3}$, and $10^{-4}$ dilutions was plated onto Petri dishes containing tryptic soy agar (TSA; BD Difco, Franklin Lakes, NJ, USA), a medium used to isolate canola bacterial endophytes in previous works $[14,15]$. Plates were incubated at $28{ }^{\circ} \mathrm{C}$ for 7 days. Individual colonies were picked and transferred to new plates containing the same media.

\subsection{MALDI-TOF MS and Data Analysis}

The sample preparation and MALDI-TOF MS analysis were carried out as described in a previous publication [28] using a matrix of saturated solution of $\alpha$-HCCA ( $\alpha$-Cyanohydroxycinnamic acid; Bruker Daltonics, Germany) in 50\% acetonitrile and 2.5\% trifluoracetic acid. We used biomass in amounts between 5 and $100 \mathrm{mg}$ to obtain the spectra, as indicated by the manufacturer. The calibration masses were the Bruker Bacterial Test Standards (BTS), which were as follows (masses as averages): RL36, 4365.3 Da; RS22, 5096.8 Da; RL34, 5381.4 Da; RL33meth, 6255.4 Da; RL29, 7274.5 Da; RS19, 10,300.1 Da; RNase A, 13,683.2 Da; and myoglobin, 16,952.3 Da.

The score values proposed by the manufacturer are as follows: a score value between 2.3 and 3.00 indicates highly probable species identification; a score value between 2.0 and 2.299 indicates secure genus identification and probable species identification; a score value between 1.7 and 1.999 indicates probable genus identification; and a score value $<1.7$ indicates no reliable identification.

Cluster analysis was performed based on the comparison of the strain-specific main spectra created, as described above. The dendrogram was constructed using the statistical toolbox of Matlab 7.1 (MathWorks Inc., Natick, MA, USA) integrated in the MALDI Biotyper 3.0 software (Bruker Daltonics, Bremen, Germany). The parameter settings were "Distance Measure = Euclidean" and "Linkage = Complete". The linkage function was normalized according to the distance between 0 (perfect match) and 1000 (no match).

\section{3. rrs Gene Analysis}

Amplification and sequencing of $r$ rs genes were carried out as indicated by Carro et al. [29]. These genes were sequenced by the Sequencing DNA Service (NUCLEUS) at Salamanca University (Spain). The obtained sequences were compared with those from GenBank using the BLASTN program against the "type strains database" [30]. The sequences were deposited in GenBank under the accessions MZ456246-MZ456285.

\subsection{Plant Growth Assays under Hydroponic Conditions}

Brassica napus var. Florida seeds (Koipesol Semillas, Sevilla, Spain) were washed six times with tap water in order to eliminate the presence of chemicals coating the commercial seeds' surfaces. Then, their surfaces were disinfected with diluted commercial bleach $(2.5 \%$ sodium hypochlorite) for $5 \mathrm{~min}$. After ten washes with sterile distilled water, seeds were placed in $1 \mathrm{~L}$ pots with sterile vermiculite. After emergence, plantlets were thinned to one per pot. The pots were randomly distributed in a greenhouse at $24 / 16^{\circ} \mathrm{C}$ with a $16 / 8 \mathrm{~h}$ photoperiod and $60 \%$ humidity, and watered three times per week with Rigaud and Puppo solution at half strength [31]. All isolates were inoculated on canola under hydroponic conditions to assess their growth-promotion potential. Given the large number of bacterial isolates to be assessed and the limited space in the greenhouse, their effect on plant performance was tested in four different batches. Each batch experiment was performed under the same environmental conditions but with its own uninoculated control treatment.

To prepare cultures for inoculation, the bacterial isolates were incubated over $48 \mathrm{~h}$ on TSA plates (Difco, BBL Becton Dickinson, Franklin Lakes, NJ, USA). Bacteria from plate cultures were resuspended in Phosphate Buffered Saline solution (PBS) to an optical density of 5 units according to the McFarland scale (approximately $1.5 \times 10^{9} \mathrm{CFU} \mathrm{mL}^{-1}$ ). One week after sowing, canola plantlets were inoculated with $1 \mathrm{~mL}$ of bacteria in PBS applied to the root collar zone. Uninoculated control treatments were established by applying 1 $\mathrm{mL}$ of sterile PBS. There were a total of seven biological replicates per treatment. Plants 
were carefully extracted from the pots 6 weeks after inoculation and shoot and root dry weights, shoot and root lengths, and growth relative efficiency (RE), with respect to the uninoculated control treatments, were determined.

\subsection{Microcosm Assay}

The isolates of each bacterial species that were shown to be efficient in promoting plant growth under hydroponic conditions were then tested in a microcosm experiment using an agricultural soil, which was collected at the experimental farm "Muñovela" owned by IRNASA (CSIC) $\left(40^{\circ} 54^{\prime} 12^{\prime \prime} \mathrm{N}, 5^{\circ} 46^{\prime} 47^{\prime \prime} \mathrm{W}\right)$. It was analyzed, in triplicate, at the IRNASA analytical service, giving the following results (mean $\pm \mathrm{SD}, n=3$ ): $\mathrm{pH}$, $6.72 \pm 0.12$; organic matter, $1.06 \% \pm 0.06 \%$; total nitrogen, $0.12 \% \pm 0.005 \%$; available $\mathrm{P}$, $28.7 \pm 3.1 \mathrm{mg} / \mathrm{kg}$; available K, $139 \pm 10.0 \mathrm{mg} / \mathrm{kg}$; available Ca, $1678 \pm 156.0 \mathrm{mg} / \mathrm{kg}$; and available $\mathrm{Mg} ; 252 \pm 7.0 \mathrm{mg} / \mathrm{kg}$. In this assay, surface-sterilized Brassica napus var. Florida seeds (Koipesol Semillas, Sevilla, Spain) were placed in 3 L pots containing a mix of sterilized sand and soil (1:3 v/v). After emergence, plantlets were thinned to one per pot. The pots were randomly distributed and maintained in the greenhouse under the same environmental conditions described above. The canola plantlets were inoculated one week after sowing with the selected isolates, as above. Uninoculated control treatments were established by applying $1 \mathrm{~mL}$ of sterile PBS. Ten biological replicates were used per treatment.

The relative content of chlorophyll was obtained with a SPAD-502PLUS (Konica Minolta, Osaka, Japan) chlorophyll meter, avoiding leaves located close to the substrate. The experiment was concluded 8 weeks after inoculation. Plants were uprooted from the pots and adhering soil was removed gently by washing in tap water. Shoots and roots were detached from each other and weighed after drying at $60{ }^{\circ} \mathrm{C}$ until a constant weight was achieved. The dried plant shoots were ground and subjected to the following chemical analyses at the IRNASA analytical service: Nitrogen content was determined by Dumas combustion in a CN628 automatic carbon-nitrogen analyzer (LECO Instruments S.L., Madrid, Spain) following the manufacturer's instructions. The macro- $(\mathrm{P}, \mathrm{K}, \mathrm{Mg}$, and $\mathrm{Ca}$ )- and microelement ( $\mathrm{Fe}, \mathrm{Cu}, \mathrm{Mn}$, and $\mathrm{Mo}$ ) contents were determined by mineralization in a mixture of nitric acid and hydrogen peroxide $(4: 1 v / v)$ using an Ethos Up HighPerformance Microwave Digestion System (Milestone, Sorisole, Italy). Samples were subjected to microwave heating with a temperature ramp ranging from room temperature to $200{ }^{\circ} \mathrm{C}$ for $40 \mathrm{~min}$, followed by maintenance at $200{ }^{\circ} \mathrm{C}$ for $15 \mathrm{~min}$. After cooling, solutions were quantitatively transferred into $25 \mathrm{~mL}$ volumetric flasks and brought up to volume with ultrapure water. The content of different elements was analyzed by ICP-OES (inductively coupled plasma optical emission spectrometry, iCAP 6300 DUO, Thermo Electron Corporation, Rugby, UK).

\subsection{Statistical Analysis}

Shoot and root lengths and dry weights, chlorophyll levels, and macro- and microelement concentration results were subjected to ANOVA analyses followed by post hoc Dunnett's one-tailed t-tests to identify inoculation treatments with means significantly higher than those of the control at $p \leq 0.05$. All statistical analyses were performed using the statistical package SPSS version 25 for Mac (SPSS Inc., Chicago, IL, USA).

\section{Results}

\subsection{MALDI-TOF MS Analysis}

The results of this analysis indicated that most of the endophytic isolates (94\%) matched with bacterial strains contained in the Biotyper 3.0 database with score values higher than 2.0. Only three isolates (6\%) were not identified through MALDI-TOF MS (Table 1). 
Table 1. Results of the MALDI-TOF MS Analysis.

\begin{tabular}{|c|c|c|}
\hline Isolates & Best Match & Score Values \\
\hline \multicolumn{3}{|l|}{$\begin{array}{c}\text { Isolates matching with score } \\
\text { values }>2.3\end{array}$} \\
\hline MRBN04, MRBN40 & Bacillus megaterium DSM $32^{\mathrm{T}}$ & $2.439,2.476$ \\
\hline MRBN48 & Bacillus subtilis DSM $10^{\mathrm{T}}$ & $2.381,2.562$ \\
\hline $\begin{array}{l}\text { MRBN01, MRBN02, MRBN05, } \\
\text { MRBN43, MRBN47 }\end{array}$ & $\begin{array}{l}\text { Paenibacillus amylolyticus DSM } \\
\qquad 11747^{\mathrm{T}}\end{array}$ & $2.375,2.301,2.309,2.320,2.310$ \\
\hline \multicolumn{3}{|l|}{$\begin{array}{c}\text { Isolates matching with score } \\
\text { values }>2.0 \text { and }<2.3\end{array}$} \\
\hline MRBN09, MRBN26, MRBN56 & $\begin{array}{l}\text { Bacillus simplex (currently Pe. } \\
\text { simplex) CS 206_1aI BRB }\end{array}$ & $2.206,2.276,2.000$ \\
\hline MRBN21 & $\begin{array}{l}\text { Bacillus niacini (currently } N \text {. } \\
\text { niacini) DSM } 2923^{\mathrm{T}}\end{array}$ & 2.082 \\
\hline $\begin{array}{c}\text { MRBN16, MRBN17.2, } \\
\text { MRBN49, MRBN50, MRBN52, } \\
\text { MRBN55 }\end{array}$ & $\begin{array}{c}\text { Paenibacillus glucanolyticus } \\
\text { DSM } 5162^{\mathrm{T}}\end{array}$ & $2.172,2.198,2.110,2.239,2.208$ \\
\hline MRBN06 & $\begin{array}{l}\text { Paenibacillus massiliensis DSM } \\
16942^{\mathrm{T}}\end{array}$ & 2.242 \\
\hline $\begin{array}{l}\text { MRBN03, MRBN15, MRBN18, } \\
\text { MRBN35, MRBN36, MRBN44 }\end{array}$ & $\begin{array}{c}\text { Paenibacillus polymyxa DSM } \\
356\end{array}$ & $\begin{array}{c}2.179,2.106,2.166,2.193,2.124, \\
2.111\end{array}$ \\
\hline MRBN17.1, MRBN23 & $\begin{array}{c}\text { Paenibacillus polymyxa DSM } \\
742\end{array}$ & $2.165,2.158$ \\
\hline MRBN31 & $\begin{array}{c}\text { Paenibacillus polymyxa DSM } \\
740\end{array}$ & $2.118,2.117$ \\
\hline MRBN45 & $\begin{array}{l}\text { Paenibacillus polymyxa DSM } \\
372\end{array}$ & 2.247 \\
\hline $\begin{array}{c}\text { VABN01, VABN02, VABN03, } \\
\text { VABN04, VABN05, VABN08, } \\
\text { VABN09, VABN10, VABN13, } \\
\text { VABN17, VABN23 }\end{array}$ & Pseudomonas koreensis 2_2 TUB & $\begin{array}{c}2.162,2.118,2.215,2.048,2.208, \\
2.073,2.138,2.221,2.055,2.146, \\
2.228\end{array}$ \\
\hline $\begin{array}{c}\text { VABN07, VABN15, VABN20, } \\
\text { VABN21, VABN22 }\end{array}$ & $\begin{array}{l}\text { Pseudomonas thivervalensis } \\
\text { DSM } 13194^{\mathrm{T}}\end{array}$ & $2.260,2.274,2.262,2.226,2.244$ \\
\hline $\begin{array}{c}\text { Isolates not identified } \\
\text { MRBN07, MRBN12, MRBN54 }\end{array}$ & Not identified & \\
\hline
\end{tabular}

Eight isolates were directly identified at the species level, since they matched, with a score value higher than 2.3, with the type strains of Paenibacillus amylolyticus, Bacillus megaterium, and Bacillus subtilis (Table 1). Thirty-seven isolates matched with values higher than 2.0 but lower than 2.3 (Table 1). Seventeen of these isolates matched with species of the genus Paenibacillus, six with the type strain of Paenibacillus glucanolyticus DSM $5162^{\mathrm{T}}$, ten isolates with different strains of Paenibacillus polymyxa, and one with the type strain of Paenibacillus massiliensis DSM $16942^{\mathrm{T}}$. Three isolates matched with the species of genus Bacillus, two with the strain Bacillus simplex CS 206_1aI BRB, and one with the type strain of Bacillus niacini DSM $2923^{\mathrm{T}}$ (Table 1). The other sixteen isolates matched with species of the genus Pseudomonas; among them, five matched with the type strain of Pseudomonas thivervalensis DSM $13194^{\mathrm{T}}$, and eleven with the strain Pseudomonas koreensis 2_2 TUB (Table 1).

\section{2. rrs Gene Analysis}

Identification was complemented by an analysis of the rrs gene sequences for all isolates showing score values higher than 2.0 but lower than 2.3 after MALDI-TOF MS analysis, as well as for those strains that were not identified by the prior methodology. Most isolates with score values higher than 2.0 but lower than 2.3 presented similarity values that were equal or near to $100 \%$ between their rrs genes and the type strains of the first matching species in the Biotyper 3.0 database (Table 2). This occurred in the isolates matching with $B$. simplex, which is currently named Peribacillus simplex, the rrs gene of which showed a $99.8 \%$ 
similarity to its type strain NBRC $15720^{\mathrm{T}}$; the isolates matching with either P. massiliensis or $P$. polymyxa, which had a $100 \%$ and $99.5 \%$ similarity to their respective type strains, $2301065^{\mathrm{T}}$ or DSM $36^{\mathrm{T}}$; and the isolates matching with Ps. thivervalensis, which had a $99.6 \%$ similarity to its type strain SBK26 ${ }^{\mathrm{T}}$. However, those isolates matching with the type strain of PS. koreensis Ps $9-14^{\mathrm{T}}$ had a lower $r$ s gene similarity $(99.5 \%)$ to said strain than with the type strain of Pseudomonas baetica a390 ${ }^{\mathrm{T}}$ (99.8\%), which is not available in the Biotyper 3.0 database (Table 2).

Table 2. Results of the rrs gene sequence analysis.

\begin{tabular}{|c|c|c|}
\hline Isolates & $\begin{array}{c}\text { Closest Type Strain } \\
\text { (Accession Number in GenBank) }\end{array}$ & Similarity $(\%)$ \\
\hline MRBN09, MRBN26, MRBN56 & $\begin{array}{c}\text { Peribacillus simplex (previously B. simplex) NBRC } 15720^{\mathrm{T}}= \\
\text { DSM } 1321^{\mathrm{T}}(\mathrm{CP} 017704.1)\end{array}$ & 99.8 \\
\hline MRBN12, MRBN54 & Bacillus taxi M5HDSG1-1 ${ }^{\mathrm{T}}$ (MK355518.1) & 99.4 \\
\hline \multirow{5}{*}{$\begin{array}{l}\text { MRBN16, MRBN17.2, MRBN49, MRBN50, } \\
\text { MRBN52, MRBN55 }\end{array}$} & $\begin{array}{l}\text { Neobacillus niacini (previously N. niacini) IFO15566 }{ }^{\mathrm{T}}=\mathrm{NBRC} \\
\text { 15566 }^{\mathrm{T}}\left(\mathrm{NR} \_024695.1, \mathrm{NR} 113777.1\right) \\
\text { Paenibacillus lautus AB236d }{ }^{\mathrm{T}}=\mathrm{JCM} 9073^{\mathrm{T}}=\mathrm{NBRC} 15380^{\mathrm{T}}\end{array}$ & 98.7 \\
\hline & (NR_117185.1, NR_040882.1, NR_112724.1) & 99.1 \\
\hline & Paenibacillus lautus NRRL NRS-666 ${ }^{\mathrm{T}}$ (NR_115599.1) & 98.5 \\
\hline & Paenibacillus glucanolyticus 5162 ${ }^{\mathrm{T}}$ (CP015286.1) & 98.3 \\
\hline & $\begin{array}{c}\text { Paenibacillus glucanolyticus DSM 5162 }{ }^{\mathrm{T}}=\mathrm{NBRC} 15330^{\mathrm{T}} \\
\text { (NR_040883.1, NR_113748.1) }\end{array}$ & 97.8 \\
\hline MRBN06 & Paenibacillus massiliensis $2301065^{\mathrm{T}}$ (NR_115175.1) & 100 \\
\hline $\begin{array}{l}\text { MRBN03, MRBN15, MRBN17.1, MRBN18, } \\
\text { MRBN23, MRBN31, MRBN35, MRBN36, } \\
\text { MRBN44, MRBN45 }\end{array}$ & Paenibacillus polymyxa DSM 36 ${ }^{\mathrm{T}}$ (CP049784.1) & 99.4 \\
\hline VABN01, VABN02, VABN03, VABN04, & Pseudomonas baetica a390 ${ }^{\mathrm{T}}$ (NR 116899.1) & 99.8 \\
\hline $\begin{array}{l}\text { VABN05, VABN08, VABN09, VABN10, } \\
\text { VABN13, VABN17, VABN23 }\end{array}$ & Pseudomonas koreensis Ps 9-14 ${ }^{\mathrm{T}}$ (NR_025228.1) & 99.5 \\
\hline $\begin{array}{c}\text { VABN07, VABN15, VABN20, VABN21, } \\
\text { VABN22 }\end{array}$ & Pseudomonas thivervalensis SBK26 ${ }^{\mathrm{T}}$ (NR_024951.1) & 99.6 \\
\hline MRBN07 & Terribacillus saccharophilus 002-048 ${ }^{\mathrm{T}}$ (NR_041356.1) & 99.9 \\
\hline
\end{tabular}

Some isolates with score values higher than 2.0 but lower than 2.3 with different species available in the Biotyper 3.0 database showed rrs gene similarity values equal to or lower than $99 \%$ with respect to the type strain of their species. This was the case for the isolate MRBN21, the rrs gene of which showed a $98.7 \%$ sequence similarity to that of the type strain of B. niacini (currently Neobacillus niacini). Additionally, the isolates determined by MALDI-TOF MS to match the type strain of P. glucanolyticus DSM $5162^{\mathrm{T}}$ showed rrs sequence similarities of less than $98 \%$ with this species but, surprisingly, had sequence similarities equal to or greater than $98.5 \%$ with respect to the type strain of Paenibacillus lautus held in different culture collections (Table 2).

Finally, the rrs gene sequences of the three isolates that were not identified through MALDI-TOF MS analysis showed 99.9\% (MRBN07) and 99.4\% (MRBN12 and MRBN54) similarity with regard to those of the type strains Terribacillus saccharophilus $002-048^{\mathrm{T}}$ and Bacillus taxi M5HDSG1- ${ }^{\mathrm{T}}$, respectively (Table 2).

\subsection{Hydroponic Conditions Test}

Inoculation of the isolates on canola seedlings grown under hydroponic conditions revealed that 24 out of 48 isolates $(50 \%)$ significantly $(p \leq 0.05)$ increased some of the measured parameters (shoot and root lengths and weights) when compared with those of the control (Table S1). Two isolates-MRBN17.2 and MRBN55, which belong to the P. glucanolyticus / P. lautus group-significantly increased all four of the measured parameters. Two isolates-Ps. thivervalensis VABN22 and P. polymyxa MRBN31-significantly increased three of the four measured parameters; five isolates-Ps. thivervalensis VANB20, $P e$. simplex MRBN26 and MRBN56, and P. amylolyticus MRBN43 and MRBN47—significantly 
increased two of the four measured parameters; and fourteen isolates-of species mostly belonging to the genera Paenibacillus and Pseudomonas - significantly increased only one of the measured parameters (Figure 1, Table S1). All isolates that significantly increased at least two parameters, and three isolates that increased only the shoot dry weight but yielded the best results for this parameter within their respective species, were chosen for further testing in the microcosm assay.

$\mathrm{RDW} \square \mathrm{RL} \square \mathrm{SDW} \square \mathrm{SL}$

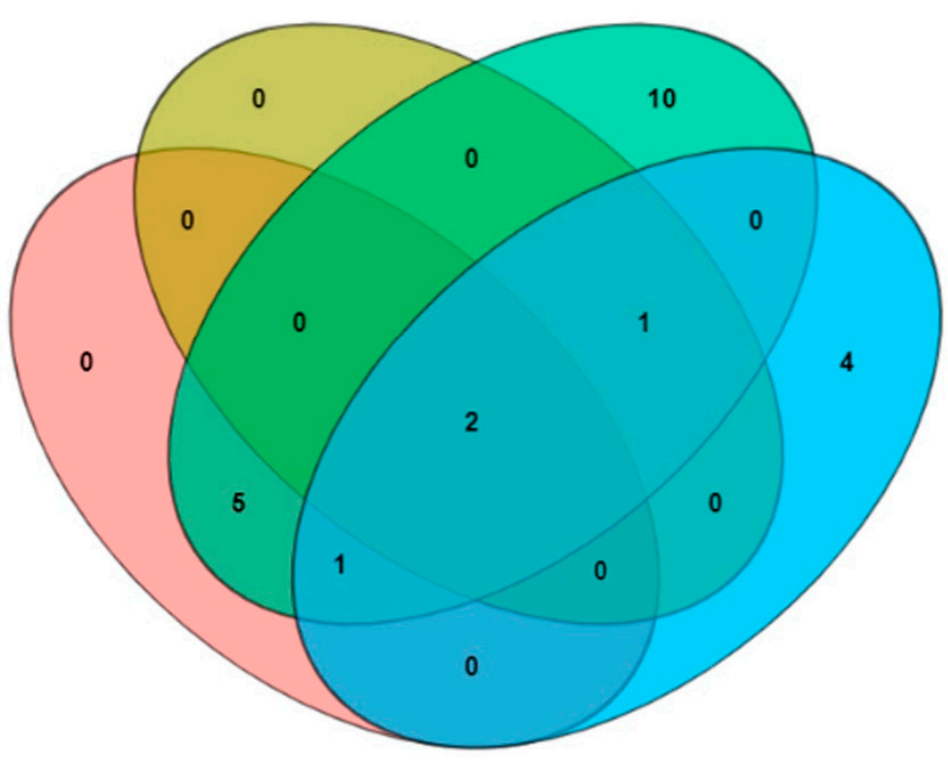

Selected strains:

Four parameters MRBN17.2 MRBN55

Three parameters VABN22 MRBN31

Two parameters VABN20

MRBN26

MRBN56

MRBN43

MRBN47

One parameter

MRBN01

MRBN45

MRBN52

VABN21

Figure 1. Four-set Venn diagram showing the number of canola endophytic isolates whose inoculation significantly increased at least one of the following growth parameters: SDW, shoot dry weight; RDW, root dry weight; SL, shoot length; $\mathrm{RL}$, root length. The bacterial isolates selected for the microcosm assay are listed at the right of the figure.

\subsection{Microcosm Assay}

The thirteen isolates selected as the best canola growth promoters under hydroponic conditions significantly increased $(p \leq 0.05)$ the shoot dry weight of canola plants, and five of these also increased the root dry weight (Table 3). Leaf chlorophyll content was significantly increased after inoculation with three of the investigated isolates (Table 3). No significant differences to the control treatment were found in the shoot concentrations of $\mathrm{N}, \mathrm{P}, \mathrm{K}, \mathrm{Ca}$, and $\mathrm{Mg}$ (Table 3). However, several isolates significantly increased ( $p \leq 0.05)$ the shoot concentrations of micronutrients such as $\mathrm{Cu}, \mathrm{Fe}, \mathrm{Mn}$, and Mo (Table 3). The isolate P. polymyxa MRBN45 significantly $(p \leq 0.05)$, or marginally significantly $(p \leq 0.10)$, increased the concentrations of three micronutrients $(\mathrm{Cu}, \mathrm{Mo}$, and $\mathrm{Fe})$, and 9 out of the 13 tested isolates increased the Mo concentration (Table 3). In terms of plant growth promotion, it is remarkable that plants inoculated with the isolates P. amylolyticus MRBN01, MRBN17.2, and MRBN55 (P. glucanolyticus/P. lautus group); P. polymyxa MRBN45; Pe. simplex MRBN26; and Ps. thivervalensis VABN21 attained or surpassed an increase of $25 \%$ in shoot dry weight compared with the control, with the maximum promoting effect $(51.7 \%$ and $44.7 \%$ more than the control in shoot and root weights, respectively) observed for the isolate P. polymyxa MRBN45 (Table 3). 
Table 3. Growth parameters and shoot mineral content of canola plants grown in an agricultural soil under greenhouse conditions and inoculated with root endophytic bacterial isolates selected as the best canola growth promoters under hydroponic conditions.

\begin{tabular}{|c|c|c|c|c|c|c|c|c|c|c|c|c|c|c|}
\hline Isolate & Species & SDW & RDW & $R E^{\S}$ & Chlorophyll ${ }^{¥}$ & $\mathbf{N}$ & $\mathbf{P}$ & K & $\mathrm{Ca}$ & $\mathrm{Mg}$ & $\mathrm{Fe}$ & $\mathrm{Cu}$ & Mn & Mo \\
\hline & & \multicolumn{2}{|c|}{$-\left(\right.$ mg plant $\left.^{-1}\right)-$} & $(\%)$ & (SPAD units) & $(\%)$ & \multicolumn{4}{|c|}{$-\left(\mathrm{mg} \mathrm{g} \mathrm{dw^{-1 }}\right)$} & \multicolumn{4}{|c|}{$-\left(\mu g \mathrm{gdw}^{-1}\right)$} \\
\hline Control & & 1609 & 369 & & 40.1 & 1.99 & 2.57 & 44.7 & 3.95 & 9.46 & 32.7 & 3.41 & 89.3 & 0.30 \\
\hline MRBN01 & $\begin{array}{l}\text { Paenibacillus } \\
\text { amylolyticus }\end{array}$ & 2009 & 497 & 125 & 43.4 & 2.03 & 2.23 & 42.8 & 2.89 & 7.36 & 44.7 & 3.30 & 73.9 & 0.36 \\
\hline MRBN17.2* & Paenibacillus sp. & 2020 & 468 & 126 & 41.6 & 1.97 & 2.52 & 44.3 & 3.06 & 7.72 & 49.8 & 3.42 & 76.7 & 0.40 \\
\hline MRBN26 & Peribacillus simplex & 2040 & 387 & 127 & 38.9 & 2.05 & 2.59 & 46.9 & 3.71 & 8.45 & 38.9 & 3.81 & 96.5 & 0.49 \\
\hline MRBN31 & $\begin{array}{c}\text { Paenibacillus } \\
\text { polymyxa }\end{array}$ & 1820 & 387 & 113 & 40.2 & 1.84 & 2.48 & 43.9 & 3.51 & 8.41 & 52.2 & 2.94 & 81.6 & 0.33 \\
\hline MRBN43 & $\begin{array}{l}\text { Paenibacillus } \\
\text { amylolyticus }\end{array}$ & 1947 & 397 & 121 & 40.9 & 2.04 & 2.63 & 46.5 & 3.47 & 7.92 & 42.3 & 3.49 & 81.9 & 0.40 \\
\hline MRBN45 & $\begin{array}{l}\text { Paenibacillus } \\
\text { polymyxa }\end{array}$ & 2441 & 534 & 152 & 44.7 & 2.02 & 2.50 & 44.5 & 3.28 & 6.87 & 57.4 & 4.53 & 94.0 & 0.68 \\
\hline MRBN47 & $\begin{array}{l}\text { Paenibacillus } \\
\text { amylolyticus }\end{array}$ & 1887 & 431 & 117 & 40.3 & 2.11 & 2.37 & 44.8 & 3.06 & 7.67 & 53.3 & 3.64 & 76.1 & 0.38 \\
\hline MRBN52* & Paenibacillus sp. & 1979 & 425 & 123 & 42.3 & 1.98 & 2.45 & 44.3 & 3.61 & 7.74 & 43.7 & 4.26 & 109.5 & 0.56 \\
\hline MRBN55* & Paenibacillus sp. & 2089 & 413 & 130 & 43.4 & 1.97 & 2.54 & 45.8 & 3.95 & 8.51 & 60.6 & 4.72 & 120.8 & 0.62 \\
\hline MRBN56 & Peribacillus simplex & 1963 & 444 & 122 & 42.4 & 2.01 & 2.72 & 46.7 & 3.96 & 8.41 & 37.5 & 4.23 & 103.4 & 0.55 \\
\hline VABN20 & $\begin{array}{l}\text { Pseudomonas } \\
\text { thivervalensis }\end{array}$ & 1849 & 412 & 115 & 42.9 & 2.09 & 2.72 & 46.8 & 3.84 & 8.12 & 44.8 & 4.61 & 111.4 & 0.60 \\
\hline VABN21 & $\begin{array}{l}\text { Pseudomonas } \\
\text { thivervalensis }\end{array}$ & 2025 & 373 & 126 & 41.2 & 2.10 & 2.62 & 43.9 & 3.40 & 7.68 & 53.7 & 3.53 & 78.2 & 0.40 \\
\hline VABN22 & $\begin{array}{l}\text { Pseudomonas } \\
\text { thivervalensis }\end{array}$ & 1760 & 457 & 109 & 41.7 & 2.14 & 2.45 & 45.6 & 3.38 & 7.51 & 68.6 & 4.74 & 99.6 & 0.58 \\
\hline
\end{tabular}

SDW, shoot dry weight; RDW, root dry weight. Means $(n=10)$ are shown. Treatment means in bold type were higher than those for the uninoculated control treatment according to Dunnett's one-tailed tests at $p \leq 0.05 .{ }^{*}$ These isolates belong to the P. glucanolyticus/P. lautus group. ${ }^{\S} \mathrm{RE}$, relative efficiency compared with the control shoot dry weight. ${ }^{\sharp}$ Chlorophyll content in leaves.

\section{Discussion}

At present, there is growing interest in bacterial endophytes since they can exert a positive effect on plant growth, but those of canola plants have rarely been studied, and their identification has been carried out primarily through $r$ rs gene sequence analysis [11-16]. In this work, we applied, for the first time, MALDI-TOF MS for the identification of canola root endophytes, as it is a rapid and reliable methodology for bacterial identification $[28,32,33]$. We completed this identification through $r r s$ gene sequencing, as has been reported for the identification of bacterial endophytes of other plant species [20,23,25].

The results of this study demonstrate that most canola endophytic root bacteria can be readily identified at the genus level by MALDI-TOF MS; they also revealed that several strains ( 9 out of 48 isolates) could be directly identified at the species level, since their score values, against the type strains of bacterial species contained in the Biotyper 3.0 database, were higher than 2.3 (Table 1). In addition, most of the bacterial strains with MALDI-TOF MS score values between 2.0 and 2.3 also returned $r$ rs gene sequence similarity values equal or near to $100 \%$ for the type strains of their respective species (Table 2). The exceptions were the isolates matching with the type strains of B. niacini (currently N. niacini) and P. glucanolyticus, the rrs gene sequences of which returned similarity values lower than $99 \%$ against their respective type strains. Discrepancies between the two methodologies could be related to the type strains for which the spectra and rrs sequences are available in the Biotyper 3.0 and GenBank databases, respectively, which come from different culture collections (Tables 1 and 2). Since further taxonomic studies will be necessary to solve the identity issues of these type strains, we have named the isolates used in this work as Neobacillus sp. and Paenibacillus sp. Only three isolates were not identified by MALDITOF MS (Table 1) because they belong to the bacterial species Bacillus taxi and Terribacilus saccharophilus, which are not included in the Biotyper 3.0 database. The absence of the species Ps. baetica in this database is also the cause of the discrepancy found in the case of the isolates matched with Ps. koreensis through MALDI-TOF MS analysis, but with P. baetica after $r r s$ gene sequencing (Tables 1 and 2). Therefore, MALDI-TOF MS is an appropriate methodology for the identification of bacterial endophytes at the genus and species level, although it will be necessary to extend the Biotyper database through the addition of more species in order to identify all bacterial species isolated from plant sources. 
Among the genera identified in this study, Pseudomonas, Bacillus, and Paenibacillus had also been found in canola roots in Belgium [13]; Pseudomonas and Bacillus had been found in Canada [34]; and Pseudomonas had been found in Brazil [12]. However, these isolates were not identified at the species level. Through 16S rRNA ( rrs) gene sequence analysis, the species Pseudomonas migulae was identified in canola roots in France [11]; Ps. viridiflava in Argentina [27]; and Ps. brassicacearum, Ps. orientalis, Ps. poae, Ps. baetica, and Ps. thivervalensis in Spain [15], of which the last two species were also found in this study. The species Bacillus aryabhattai, B. safensis, B. siamensis, B. megaterium, and B. simplex were also identified in canola roots in Spain [15], of which the last two species were, again, found in this study. The species $B$. simplex has been recently reclassified as Peribacillus simplex, and the species Bacillus niacini has been reclassified as Neobacillus niacini [35], of which only P. simplex (previously B. simplex) was also found in the previous study of Jiménez-Gómez et al. [15]. In this study, we reported. for the first time. the species $N$. niacini, B. subtilis, B. taxi, T. saccharophilus, P. polymyxa, P. amylolyticus, and P. massiliensis, as well as the P. glucanolyticus/P. lautus group, as endophytes of canola roots.

Some isolates from the two Pseudomonas species identified in this study promoted shoot and root growth under hydroponic conditions (Table S1). Of particular note, those of Ps. thivervalensis also significantly increased the shoot weight under microcosm (agricultural soil) conditions (Table 3). These results are in agreement with those found in previous studies either under hydroponic or microcosm conditions, in which inoculation with Pseudomonas isolates increased shoot and/or root dry weights [11,12,27], or shoot and root lengths [15]. Nevertheless, the most effective isolates in this work belonged to Ps. thivervalensis, a species that has not been previously reported as a canola growth promoter, since the strains isolated to date belonged to the species Ps. migulae [11], Ps. viridiflava [27], Ps. baetica, or Ps. brassicacearum [15], or were not identified at the species level [12].

With respect to the sporulating species isolated from canola roots, existing data concerning their ability to increase canola growth are scarce. Jiménez-Gómez et al. [15] demonstrated, under hydroponic conditions, that inoculation with one strain of Pe. simplex (previously B. simplex) increased the shoot and root lengths of canola plantlets. Although the two isolates of this species studied in this work did not increase these parameters, they significantly increased the shoot and root weights not only under hydroponic conditions (Table S1), but also in microcosms (Table 3). In addition, we showed, for the first time, that isolates of several Paenibacillus species can promote canola growth in microcosm conditions, and are therefore promising candidates for the biofertilization of this highly important crop. Although they demonstrated a similar performance to the Pseudomonas isolates on canola plants, sporulating bacteria have technological advantages over non-sporulating ones because of the suitability of their endospores for dry formulations, which facilitates improved preservation and handling of biofertilizers by farmers. Moreover, endospores are resistant to stresses such as heat, radiation, and desiccation, which favor the persistence of inoculants in the environment [36].

\section{Conclusions}

The endophytic bacteria isolated from canola roots in this work belonged to the gram-negative genus Pseudomonas and to different species of the gram-positive sporulating genera Bacillus, Neobacillus, Paenibacillus, Peribacillus, and Terribacillus. Some species could be directly identified by MALDI-TOF MS, such as B. megaterium, B. subtilis, and P. amylolyticus. The identification of isolates from the species P. massiliensis, P. polymyxa, Pe. simplex, Ps. thivervalensis, Paenibacillus sp. (P. glucanolyticus/P. lautus group), and Neobacillus sp. was confirmed by rrs gene sequencing. Finally, the bacterial species Ps. baetica, B. taxi, and T. saccharophilus were only identified through $r$ rs gene sequencing, since they are not currently included in the Biotyper 3.0 database. Fifty percent of the isolates significantly increased some of the parameters measured in canola plants grown hydroponically in vermiculite, as compared with the control. The thirteen isolates selected as the best performers in hydroponic conditions also increased canola growth when tested in agricultural soil 
under greenhouse conditions. It is remarkable that sporulating isolates of $P$. amylolyticus, P. polymyxa, Paenibacillus sp. (P. glucanolyticus/P. lautus group), and Pe. simplex (previously B. simplex) promoted canola shoot growth equally or more efficiently than Ps. thivervalensis. Owing to their biotechnological advantages in the formulation of biofertilizers, these sporulating rods are the most promising inoculants for canola crops.

Supplementary Materials: The following are available online at https:/ /www.mdpi.com/article/10 .3390/agronomy11091796/s1, Supplementary Table S1: Growth parameters of canola plants grown under hydroponic conditions and inoculated with root endophytic bacterial isolates.

Author Contributions: Conceptualization, E.V., R.R., P.F.M., Á.P., J.M.I. and E.M.-M.; methodology, P.M.-H., J.D.F.-F., F.S.-J. and E.V; validation, E.V., F.S.-J., R.R., P.F.M., Á.P., J.M.I. and E.M.-M.; formal analysis, E.V., R.R., P.F.M., Á.P., J.M.I. and E.M.-M.; investigation, P.M.-H., J.D.F.-F. and F.S.-J.; data curation, P.M.-H., J.D.F.-F., F.S.-J. and E.V.; writing-original draft preparation, P.M.-H., J.D.F.-F., and F.S.J.; writing-review and editing, E.V., R.R., P.F.M., Á.P., J.M.I., I.S.R. and E.M.-M.; supervision, E.V. and E.M.-M.; project administration, E.M.-M. and I.S.R.; funding acquisition, E.M.-M. and I.S.R. All authors have read and agreed to the published version of the manuscript.

Funding: This work was supported by JCyL (Junta de Castilla y León, Spanish Regional Government) Grant SA058U16 to EMM and Project "CLU-2019-05-IRNASA/CSIC Unit of Excellence", funded by the Junta de Castilla y León and cofinanced by the European Union (ERDF "Europe drives our growth").

Acknowledgments: The authors thank the Strategic Research Programs for Units of Excellence from Junta de Castilla y León (CLU-2O18-04).

Conflicts of Interest: The authors declare no conflict of interest.

\section{References}

1. Loganes, C.; Ballali, S.; Minto, C. Main Properties of Canola Oil Components: A Descriptive Review of Current Knowledge. Open Agric. J. 2016, 10, 69-74. [CrossRef]

2. Ge, J.C.; Yoon, S.K.; Choi, N.J. Using canola oil biodiesel as an alternative fuel in diesel engines: A review. Appl. Sci. $2017,7,881$. [CrossRef]

3. Hegewald, H.; Wensch-Dorendorf, M.; Sieling, K.; Christen, O. Impacts of break crops and crop rotations on oilseed rape productivity: A review. Eur. J. Agron. 2018, 101, 63-77. [CrossRef]

4. Food and Agriculture Organization of the United Nations (FAO). Available online: http://www.fao.org/faostat/en/\#data/QC (accessed on 1 April 2021).

5. Fernández-Tirado, F.; Parra-López, C.; Romero-Gámez, M. A multi-criteria sustainability assessment for biodiesel alternatives in Spain: Life cycle assessment normalization and weighting. Renew. Energy 2021, 164, 1195-1203. [CrossRef]

6. Riaz, U.; Mehdi, S.M.; Iqbal, S.; Khalid, H.I.; Qadir, A.A.; Anum, W.; Ahmad, M.; Murtaza, G. Bio-fertilizers: Eco-Friendly Approach for Plant and Soil Environment. In Bioremediation and Biotechnology; Hakeem, K., Bhat, R., Qadri, H., Eds.; Springer: Cham, Switzerland, 2020; pp. 189-213.

7. Thomas, L.; Singh, I. Microbial Biofertilizers: Types and Applications. In Biofertilizers for Sustainable Agriculture and Environment; Giri, B., Prasad, R., Wu, Q.S., Varma, A., Eds.; Springer: Cham, Switzerland, 2019; pp. 1-19.

8. Santoyo, G.; Moreno-Hagelsieb, G.; Orozco-Mosqueda, M.C.; Glick, B.R. Plant growth-promoting bacterial endophytes. Microbiol. Res. 2016, 183, 92-99. [CrossRef]

9. Afzal, I.; Shinwari, Z.K.; Sikandar, S.; Shahzad, S. Plant beneficial endophytic bacteria: Mechanisms, diversity, host range and genetic determinants. Microbiol. Res. 2019, 221, 36-49. [CrossRef]

10. Omomowo, O.I.; Babalola, O.O. Bacterial and Fungal Endophytes: Tiny giants with immense beneficial potential for plant growth and sustainable agricultural productivity. Microorganisms 2019, 7, 481. [CrossRef]

11. Bertrand, H.; Nalin, R.; Bally, R.; Cleyet-Marel, J.C. Isolation and identification of the most efficient plant growth-promoting bacteria associated with canola (Brassica napus). Biol. Fertil. Soils 2001, 33, 152-156. [CrossRef]

12. Farina, R.; Beneduzi, A.; Ambrosini, A.; de Campos, S.B.; Lisboa, B.B.; Wendisch, V.; Vargas, L.K.; Passaglia, L.M. Diversity of plant growth-promoting rhizobacteria communities associated with the stages of canola growth. Appl. Soil Ecol. 2012, 55, 44-52. [CrossRef]

13. Croes, S.; Weyens, N.; Colpaert, J.; Vangronsveld, J. Characterization of the cultivable bacterial populations associated with field grown Brassica napus L.: An evaluation of sampling and isolation protocols. Environ. Microbiol. 2015, 17, 2379-2392. [CrossRef]

14. Valetti, L.; Iriarte, L.; Fabra, A. Growth promotion of rapeseed (Brassica napus) associated with the inoculation of phosphate solubilizing bacteria. Appl. Soil Ecol. 2018, 132, 1-10. [CrossRef] 
15. Jiménez-Gómez, A.; Saati-Santamaría, Z.; Kostovcik, M.; Rivas, R.; Velázquez, E.; Mateos, P.F.; Menéndez, E.; García-Fraile, P. Selection of the root endophyte Pseudomonas brassicacearum CDVBN10 as plant growth promoter for Brassica napus L. crops. Agronomy 2020, 10, 1788. [CrossRef]

16. Jamalzadeh, A.; Darvishnia, M.; Khodakaramian, G.; Bazgir, E.; Zafari, D. Genetic diversity and plant growth-promoting activity of the dominant bacteria from canola plants in Western Iran. Egypt. J. Biol. Pest Control 2021, 31, 98. [CrossRef]

17. Lagier, J.C.; Armougom, F.; Million, M.; Hugon, P.; Pagnier, I.; Robert, C.; Bittar, F.; Fournous, G.; Gimenez, G.; Maraninchi, M.; et al. Microbial culturomics: Paradigm shift in the human gut microbiome study. Clin. Microbiol. Infect. 2012, 18, 1185-1193. [CrossRef] [PubMed]

18. Lagier, J.C.; Dubourg, G.; Million, M.; Cadoret, F.; Bilen, M.; Fenollar, F.; Levasseur, A.; Rolain, J.M.; Fournier, P.E.; Raoult, D. Culturing the human microbiota and culturomics. Nat. Rev. Microbiol. 2018, 16, 540-550. [CrossRef] [PubMed]

19. Sarhan, M.S.; Hamza, M.A.; Youssef, H.H.; Patz, S.; Becker, M.; ElSawey, H.; Nemr, R.; Daanaa, H.S.A.; Mourad, E.F.; Morsi, A.T.; et al. Culturomics of the plant prokaryotic microbiome and the dawn of plant-based culture media-A review. J. Adv. Res. 2019, 19, 15-27. [CrossRef]

20. Nyambura-Ngamau, C.; Njeri-Matiru, V.; Tani, A.; Wangari-Muthuri, C. Isolation and identification of endophytic bacteria of bananas (Musa spp.) in Kenya and their potential as biofertilizers for sustainable banana production. Afr. J. Microbiol. Res. 2012, 6, 6414-6422. [CrossRef]

21. Stets, M.I.; Pinto, A.S., Jr.; Huergo, L.F.; de Souza, E.M.; Guimarães, V.F.; Alves, A.C.; Steffens, M.B.; Monteiro, R.A.; Pedrosa, F.d.Q.; Cruz, L.M.; et al. Rapid identification of bacterial isolates from wheat roots by high resolution whole cell MALDI-TOF MS analysis. J. Biotechnol. 2013, 165, 167-174. [CrossRef]

22. Velázquez, E.; Menéndez, E.; Sánchez-Juanes, F.; Valencia-Daza, N.; Pérez-Yépez, J.; León Barrios, M.; Pérez-Galdona, R.; Garrido, A.; González-Buitrago, J.M. Identification of human pathogenic bacteria in plant roots by using MALDI-TOF MS methodology. In Biological Nitrogen Fixation and Beneficial Plant-Microbe Interaction; González-Andrés, F., James, E., Eds.; Springer: Cham, Switzerland, 2016; pp. 3-12.

23. López, J.L.; Alvarez, F.; Príncipe, A.; Salas, M.E.; Lozano, M.J.; Draghi, W.O.; Jofré, E.; Lagares, A. Isolation, taxonomic analysis, and phenotypic characterization of bacterial endophytes present in alfalfa (Medicago sativa) seeds. J. Biotechnol. 2018, $267,55-62$. [CrossRef]

24. Toubal, S.; Bouchenak, O.; Elhaddad, D.; Yahiaoui, K.; Boumaza, S.; Arab, K. MALDI-TOF MS detection of endophytic bacteria associated with great nettle (Urtica dioica L.), grown in Algeria. Pol. J. Microbiol. 2018, 67, 67-72. [CrossRef] [PubMed]

25. LaMontagne, M.G.; Tran, P.L.; Benavidez, A.; Morano, L.D. Development of an inexpensive matrix-assisted laser desorptiontime of flight mass spectrometry method for the identification of endophytes and rhizobacteria cultured from the microbiome associated with maize. PeerJ 2021, 9, e11359. [CrossRef]

26. Compant, S.; Samad, A.; Faist, H.; Sessitsch, A. A review on the plant microbiome: Ecology, functions, and emerging trends in microbial application. J. Adv. Res. 2019, 19, 29-37. [CrossRef]

27. Romero, F.M.; Rossi, F.R.; Gárriz, A.; Carrasco, P.; Ruíz, O.A. A bacterial endophyte from apoplast fluids protects canola plants from different phytopathogens via antibiosis and induction of host resistance. Phytopathology 2019, 109, 375-383. [CrossRef] [PubMed]

28. Ferreira, L.; Sánchez-Juanes, F.; García-Fraile, P.; Rivas, R.; Mateos, P.F.; Martínez-Molina, E.; González-Buitrago, J.M.; Velázquez, E. MALDI-TOF mass spectrometry is a fast and reliable platform for identification and ecological studies of species from family Rhizobiaceae. PLoS ONE 2011, 6, e20223. [CrossRef]

29. Carro, L.; Spröer, C.; Alonso, P.; Trujillo, M.E. Diversity of Micromonospora strains isolated from nitrogen fixing nodules and rhizosphere of Pisum sativum analyzed by multilocus sequence analysis. Syst. Appl. Microbiol. 2012, 35, 73-80. [CrossRef]

30. Altschul, S.F.; Gish, W.; Miller, W.; Myers, E.W.; Lipman, D.J. Basic local alignment search tool. J. Mol. Biol. 1990, 215, 403-410. [CrossRef]

31. Rigaud, J.; Puppo, A. Indole-3-acetic acid catabolism by soybean bacteroids. J. Gen. Microbiol. 1975, 88, 223-228. [CrossRef]

32. Rychert, J. Benefits and limitations of MALDI-TOF Mass Spectrometry for the identification of microorganisms. J. Infectiol. 2019, 2, 1-5. [CrossRef]

33. Rahi, P.; Vaishampayan, P. Editorial: MALDI-TOF MS application in Microbial Ecology studies. Front. Microbiol. 2020, 10, 2954. [CrossRef]

34. Germida, J.J.; Siciliano, S.D.; Renato de Freitas, J.; Seib, A.M. Diversity of root-associated bacteria associated with field-grown canola (Brassica napus L.) and wheat (Triticum aestivum L.). FEMS Microbiol. Ecol. 1998, 26, 43-50. [CrossRef]

35. Patel, S.; Gupta, R.S. A phylogenomic and comparative genomic framework for resolving the polyphyly of the genus Bacillus: Proposal for six new genera of Bacillus species, Peribacillus gen. nov., Cytobacillus gen. nov., Mesobacillus gen. nov., Neobacillus gen. nov., Metabacillus gen. nov. and Alkalihalobacillus gen. nov. Int. J. Syst. Evol. Microbiol. 2020, 70, 406-438. [PubMed]

36. Kaminsky, L.M.; Trexler, R.V.; Malik, R.J.; Hockett, K.L.; Bell, T.H. The inherent conflicts in developing soil microbial inoculants. Trends Biotechnol. 2019, 37, 140-151. [CrossRef] [PubMed] 